Alfrid Bustanov*

\title{
On Emotional Grounds: Private Communication of Muslims in Late Imperial Russia
}

https://doi.org/10.1515/asia-2019-0026

\begin{abstract}
This article explores the practices of private communication of Muslims at the eclipse of the Russian empire. The correspondence of a young Kazan mullah with his family and friends lays the ground for an analysis of subjectivity at the intersection of literary models and personal experience. In personal writings, individuals selected from a repertoire of available tools for self-fashioning, be that the usage of notebooks, the Russian or Muslim calendar, or peculiarities of situational language use. Letters carried the emotions of their writers as well as evoking emotions in their readers. While still having access to the Persianate models of the self, practiced by previous generations of Tatar students in Bukhara, the new generation prioritized another type of scholarly persona, based on the mastery of Arabic, the study of the Qur'an and the hadith, as well as social activism.
\end{abstract}

Keywords: personhood, history of emotions, scholarly persona, subjectivity, Islam in Russia

\section{Introduction}

Is it possible to know what the Muslims of the Russian Empire were talking about on a daily basis? I suggest that by turning our attention to ego-documents, we can discover the whole world of personal opinions as expressed in writing. Such an approach seems especially intriguing, as the current historiography of Islam in Russia tends to focus prevailingly on metanarratives such as theological and legal discourses, or on Muslims' administrative relations with the state, thus leaving aside the whole spectrum of ways in which an individual could express her- or himself. In their personal texts, individuals were free to perform their personhood, and they did that in language that they found appropriate. This 'direct speech' is of course not completely free from external constraints,

*Corresponding author: Alfrid Bustanov, Faculty of Humanities Capaciteitsgroep Europese studies, University of Amsterdam, Kloveniersburgwal 48, Amsterdam 1012 CX, Netherlands. E-mail: A.Bustanov@uva.nl 
especially when rules of the genre dictated the narrative form that a writer followed. However, it is precisely in the interplay with established prescriptions that we witness subjectivity in action. ${ }^{1}$

Thousands of private letters penned by Muslim individuals in Russia have survived to our day in public and private archives. Albeit unevenly, this body of manuscript texts covers the last two centuries, and it sheds light on everyday life and social textures of Muslim societies. Often, the documents that have been passed down to us were written and collected by ordinary imams and their relatives and friends: low-ranking personalities who otherwise rarely appear on our radar because they did not leave a significant trace of theological works. But even the well-known personalities who did write theological or historical works still have a lot to offer our study of subjectivity, for their intellectual legacy usually conceals a plethora of ways in which the given individual acted in the personal domain. The wealth and richness of this material remains almost completely neglected in ongoing discussions on state and Muslim society in the Russian Empire and the Soviet Union. I argue that by studying the various genres that usually do not make it into historiographical, theological, cultural, political and socio-economic studies, we are able to recover, at least in part, the world of a multi-voiced conversation on the matters that individuals of the past found most relevant in their everyday life.

Reading this vast body of texts can provide us a clearer, even if still very fragmented, ${ }^{2}$ view on the textures of horizontal communication among the Muslim citizens of the Russian Empire. By horizontal communication I mean societal exchange that goes beyond the purely vertical bureaucratic paperwork associated with state institutions, such as the Muftiate in Ufa, established in 1788. ${ }^{3}$ This change in focus, away from texts addressing official bodies, allows us to look beyond the strictly hierarchical framework of power and authority enshrined in the Muftiate system. ${ }^{4}$

What I offer below is an attempt to step into a previously untapped terrain of cultural production in Muslim Russia: the field of private, horizontal communication among members of the Muslim community. The key theme that I reflect upon in this article is the mechanics of internal communicative strategies in the

1 Rosenwein/Cristiani 2018: 82.

2 For a useful reminder of how fragmented the mass historical sources are see Zadeh 2016: $1-64$.

3 In this approach I follow the lead of Gagan D. S. Sood, elaborated in his monograph: India and the Islamic Heartlands: An Eighteenth-Century World of Circulation and Exchange (Sood 2016). For the study of petitions and similar documents by Russia's Muslims, see Meyer 2013: 485-505.

4 Bustanov/Kemper 2017: 130-131. 
context of late Imperial Russia. By mapping communication processes, I hope to identify the topics, formulas and peculiarities of language use in letters. What matters were of immediate importance to Russia's Muslims at the turn of the century? What could be stated explicitly, and what was intended to be read between the lines? How did the Islamicate networks of information exchange function in Russia, across existing administrative and regional boundaries?

To find answers to these questions, I first outline the structural and stylistic norms of Muslim letter-writing in the early $20^{\text {th }}$ century. Production of letters followed certain models which were meaningful to a given audience. These models must have been subject to change (in particular, it would be interesting to compare the epistolary models found in late $18^{\text {th }}$ century manuscripts, printed instructions for letter writing, and the actual practice of private correspondence in the course of the $19^{\text {th }}$ and $20^{\text {th }}$ centuries); however, their long-term development remains beyond the scope of this article.

Against the background of epistolary models, I will then introduce the emergence of the self-reflective Muslim individual at the turn of the century, through the example of Isma'il 'Abidi, a young student travelling to Medina. 'Abidi penned writings that were full of emotional expressions; it is not likely that they were meant for publication. From his letters we learn not only about the character of relations among the madrasa students, but also their perception of education abroad.

Today, what survives of Isma'il 'Abidi's private documents is split between two archives in St Petersburg and Kazan. As a whole, this archive contains both incoming and outgoing personal correspondence that has nothing to do with state institutions. Instead, we encounter the topics of immediate concern to the writers and addressees, including emotions connected to personal situations, relationships with family and friends, as well as education. The theater of these expressions of the self were the urban settings of Kazan, Mecca and Medina.

Islam in the Russian cities of the early twentieth century has become an object of scholarly inquiry in a series of important works. The period under consideration is usually described in terms of political activism (including the short experience of parliamentarism $)^{5}$, the educational reform movement, ${ }^{6}$ the secularization process, ${ }^{7}$ and the boom of journalism. ${ }^{8}$ Probably no other period in the history of Russia's Islam has been better researched, and is better archived, than the years between the two Russian Revolutions of 1905 and

5 Usmanova 2006; Usmanova 1998; Bospflug 2017.

6 Naganawa 2007a.

7 Tuna 2011.

8 Babadjanov 2007; Gosmanov/Mardanov 2014; Mardanov 2001; Usmanova 1996; Usmanova 2013. 
1917. Particularly relevant is the research of Danielle Ross, who has published extensively on the generation of Tatar students who received their religious upbringing in Russian towns. Danielle Ross points at the generational conflict and effectively demonstrates that "the "ulama sons" decided to abandon the clerical path of their fathers and went beyond strictly religious education. ${ }^{9}$ Ross describes "a transitional generation" that could not simply join either the reformist project of their fathers or the political projects of Russian or Ottoman youth. ${ }^{10}$ Equally important is the work of Norihiro Naganawa, who has revealed the prominence of the public sphere that Muslims established in the urban settings of Russian towns. ${ }^{11}$ In contrast to texts related to public life in the Russian cities, in the private realm the implications of political rhetoric are less visible, and other aspects of sociability come to the fore. Importantly, moving away from matters directly associated with the state does not mean that I emphasize a self-isolation of Muslim communities. The opposite is true: in the private realm we discover other, and more, forms of communication including beyond the Muslim community - that have hitherto gone unnoticed.

\section{Letter as a formula}

Letter-writing produced a discursive space between the formal rules of the genre ${ }^{12}$ that had to be strictly followed, on the one hand, and the actual content, emotions and impression (täessir) expected by the addressee, on the other. ${ }^{13}$ Already at school, children were introduced to the art of letter-writing. In the textbooks of Tatar students, we regularly find model letters for how to write to relatives, to a teacher and even to a romantic partner. In some cases, these patterns include a brief invocation of God and an extensive greeting by the writer in a mix of Arabic, Persian and Tatar languages. ${ }^{14}$ The name of the addressee in such cases is replaced by the placeholder fulan ("a certain"). Students often had to write to their parents back

9 Ross 2012; Ross 2019.

10 Ross 2015.

11 Naganawa 2017.

12 A stimulating discussion of letters as "not a genre": Jolly/Stanley 2005: 91-118.

13 A detailed account of the composition and circulation of Muslim letters is to be found in: Sood 2007: 172-214.

14 For example: a textbook copied by Hafiz al-Din b. Muhammad Yusuf in 1871, Institute of Oriental Manuscripts (St Petersburg), Ms. A1249, ff. 6b-7b. Quite tellingly, a card description of this item, compiled by the Institute workers in Soviet times, claims that this manuscript lacks any historical value, and hence, as most of the Tatar texts in the same collection, it was never catalogued. 
home, to ask for money or other things; for this purpose, they could also use printed instructions for letter-writing. Often, private letters included snippets from poetry, be that self-composed verses or the work of another author. ${ }^{15}$ References to the Qur'an and Sunna were also a normative practice that did not require much commentary or translation, and which expressed pious ethics and respect towards the esteemed addressee. ${ }^{16}$ Usually, each letter bears a date and the signature of the writer. For those who could not compose letters themselves, a special service was offered by scribes: for a reasonable price, the scribe - usually a mullah without much grounding in scholarship - would commit to paper everything that the customer dictated. For example, in the 1900s, Muhammad 'Arif b. 'Abd al-Latif, a citizen of Kazan, took notes on whom he wrote letters for on request, when, and for what price. In particular, someone ordered four letters in 1903 to imam Bayazid b. Hayrullah, residing in Daghestan, that cost 50 kopeks each. ${ }^{17}$ By the early twentieth century, most of the private letters were dated according to the Julian calendar, both for the years and months, sometimes mixed with the Muslim names of the months. ${ }^{18}$ The choice of calendar was also a matter of preference: Shihab al-Din al-Mardjani explicitly prohibited his students from using the Russian language and calendar on his gravestone. ${ }^{19}$ However, Muslims of Russia did not exclusively live according to the Muslim calendar, but shared the calendar of the rest of empire, even in their letters to other Muslims. Of course, from the point of religious pragmatics it remained crucial to keep to the exact days of Muslim fasting and related feasts, but even those had long been identified on the official calendar; that is, again with Muslim and Christian dates combined. ${ }^{20}$

The backs of letters often bear red seals with the imprints of their senders' initials. On the outside of the letter, one usually finds a short address line with the

15 Märdanov 2013, 2018; Khakov 1972: 196-218; Bustanov 2017: 199-224. Important to note in this regard is that the main features of Tatar epistolary genre (including the use of Arabic script) persisted until the 1980s.

16 Gully 2008; Isaev 2019: 157-162; 179-202.

17 A notebook of Muhammad 'Arif b. 'Abd al-Latif. Institute of Oriental Manuscripts (St Petersburg), A1566, ff. 82a-83a.

18 The first experiments with Christian calendar seem to go back to the mid-18 ${ }^{\text {th }}$ century: Kazan University Library, Ms. 3234 Ar., f. 1a.

19 Shäräf 1333/1915.

20 A letter by Isma'il 'Abidi from Mecca to his parents in Kazan (July 18, 1911), Institute of Language, Literature, and Arts of the Academy of Sciences of the Republic of Tatarstan. F. 53 (from here on referred to as the Vakhidi archive). Op. 5, D. 13. f. 4b. Notably, discussions around the exact days of Ramadan, times of prayers and annual feasts form a stable topic of religious discussions among the Muslims of Russia, also during the Soviet era and up to the present day. The private archive of 'Abd al-Bari Isaev in St Petersburg contains a rich documentation of the Soviet-era fatwas on the topic. Cf. Naganawa 2012b; Green 2013. 
name and place of the addressee, accompanied by the formula "may [this letter] reach the honorable hands of ... " (virelsä ide ... neng möbaräk älenä). Addresses are often written both in Russian and Tatar, indicating the use of the official postal system, ${ }^{21}$ instead of letter exchange via private networks of contacts. For example, a typical address in the early $20^{\text {th }}$ century would look as follows:

آدريس شريف مخدوم كه سبحانقولوف Въ городъ Троицкъ Орембур. губ. указны мулла ишанъ Субханколову 4е мечети свой дом,

which can be translated as "The address of Sharif Makhdum Subhanqulov. ${ }^{22}$ To the city of Troitsk of the Orenburg governorate to the licensed mullah Ishan Subhanqulov, the fourth mosque, a separate apartment."23 Relevant names and addresses were also listed in notebooks, from which we can draw inferences about the geography and types of horizontal communication.

A recognizable set of stable clichés for composing letters of a personal and semiofficial character was to be followed by writers, regardless their background. For example, a private letter of the famous Kazan Orientalist Nikolay Katanov (1862$1922)^{24}$ to an imam of the 'Uthmaniyya mosque in the city, 'Arifullah al-Salihi (18611915), provides a good illustration for this standard letter form: while asking for proofs (dala'il) from the Qur'an on the passages from a book that Katanov had to review in his function as official censor of Muslim publications, the scholar reproduced each and every point of the traditional genre of letter writing as accepted among the Tatars. ${ }^{25}$ For example, at the end of his letter, Katanov expresses a hope that this envelope will reach the addressee with Qitmir, the dog that accompanied the "Seven Sleepers of Ephesus" mentioned in the Qur'an ${ }^{26}$ (the word qitmir is often

21 Tuna 2015: 31. Surprisingly, almost no research has been done on how the postal system functioned in the Russian Empire. A recent exception is Randolph 2017. Cf. Sood 2009: 10851116.

22 From 1887, Muhammad Sharif Subhanqulov (b. 1839) served as a second imam of the fourth mosque and Sufi authority in Troitsk, see: Rahmatullin 1947; Denisov 2011: 46.

23 A notebook of Bilal al-Din al-'Abidi, Institute of Oriental Manuscripts (St Petersburg), Ms. B2561, f. 8b.

24 Geraci 2001: chapter 9.

25 Institute of Oriental Manuscripts (St Petersburg), Ms. B2680 VIII, f. 4a. This letter survived among the uncatalogued papers of 'Arifullah al-Salihi and entered the Institute collection together with a portion of Said Vakhidi's library in 1934. 'Arifullah al-Salihi was on friendly terms with Bilal al-Din al-'Abidi, whose son is the protagonist of this article. There is a short note in Bilal al-Din's notebook saying that on May 13, 1900 he borrowed a book from 'Arifullah, an imam of the 'Uthmaniyya mosque in Kazan: A notebook of Bilal al-Din al-'Abidi, Institute of Oriental Manuscripts (St Petersburg), Ms. B2561, f. 9a.

26 Paret (n.d.) "Așhāa al-Kahf”, Encyclopaedia of Islam, Second Edition. Consulted online on March 6, 2018 (http://referenceworks.brillonline.com/entries/encyclopaedia-of-islam-2/ashab- 
present on the letters as a sign of insurance and mystical protection). Notably, not only in the late tsarist but also in the early Soviet era, many Russian Orientalists maintained correspondence with the members of the Muslim intelligentsia and religious elites, writing in accordance with the Islamic literary tradition. To give an example that comes from outside the scholarly circles, I know of at least one letter that follows the rules of Muslim epistolary genre, but was penned by a person with a Christian name: Stepan b. Vasilii Lemin. ${ }^{27}$ In addition, a similar phenomenon can be observed in the circulation of Muslim love poetry in Cyrillic script in the first half of the nineteenth century, clearly reflecting the readership as lying beyond strictly Muslim communities. ${ }^{28}$ I believe that these facts testify to the existence of a shared discursive field between actors of communication, which allowed a broader circulation of Islamicate models and contents in the imperial context. ${ }^{29}$

The outer appearance of the letter (Figure 1) often played a significant role, since it also conveyed a message to be grasped by the reader. While a carefully produced letter would entail calligraphic handwriting plus strict adherence to a textual frame, ${ }^{30}$ a completely different message would be conveyed by sending a postcard with a photograph on the back of the main text; not only does the postcard add visual material, and thus non-verbal communication, but it also eliminates the privacy of the written text if no sealed envelope is used.

\section{The Muslim individual}

Isma'il 'Abidi was born in Kazan's Bishbalta ${ }^{31}$ district on August 8, 1891. He was clearly a representative of Muslim urban culture, and his correspondence predominantly sheds light on cultural exchange in the urban setting. However, his grandparents had lived in the village of Suïqsu on the

al-kahf-SIM_0773?s.num=1\&s.rows=20\&s.mode=DEFAULT\&s.f.s2_parent=encyclopaedia-ofislam-2\&s.start=0\&s.q=kitmir).

27 A letter to Fathullah al-Urawi (November 18, 1834), Institute of Oriental Manuscripts (St Petersburg), B3476. Document 42, ff. 66a, 72b. At the end, Stepan asks his addressee to forgive him his mistakes in Tatar.

28 A fragment of 'Abd al-Jabbar al-Qandali's (1797-1860) poem written in Cyrillic survived as part of the manuscript cover: Kazan University Library, Ms. 234 F, f. 1b; analyzed in Fathi 2018.

29 Cf. Sartori 2018: 143.

30 Polosin 2015.

31 Bishbalta (literally: "five axes") refers to a settlement opposite the Kazan Kremlin, on the other side of the Kazanka River. The Russian designation of the same place would be an Admiralty Settlement (Admiralteiskaia sloboda), meaning a place where the ships are produced. Cf. Faizrakhmanov 2014: 76-82. 


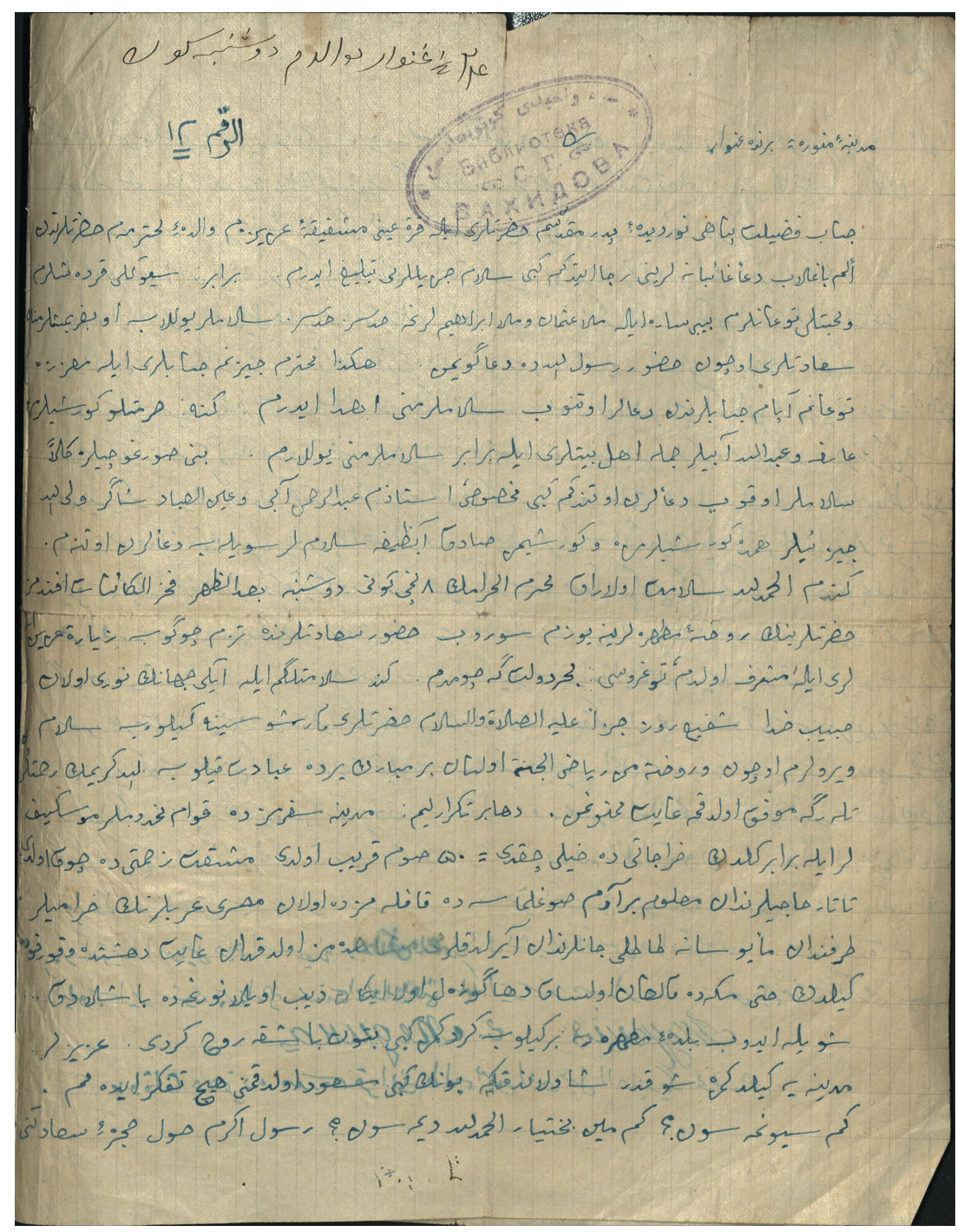

Figure 1: Isma'il ‘Abidi’s letter to his parents. January 1, 1911.

The Vakhidi archive. Op. 5. D. 13, f. 28b.

Hillside (Jabalistan ${ }^{32}$ ) of the Volga River, where his grandfather 'Abid b. Münke (d. 1864?) served as a village imam. The biography of Isma'il's father

32 Since medieval times, the term Jabalistan (a Persian equivalent for a Tatar term, taw yaghi) referred to the area on the left bank of the Volga River. This conservative designation that we encounter in the attributive names of scholars (al-Jabali, al-Jabalistani) reveals some of the 
Bilal al-Din (1840-1918) was typical for a nineteenth-century Muslim scholar: for many years he studied in Bukhara, where he entered the Naqshbandiyya mujaddidiyya brotherhood. Upon his return, he became an imam in Bishbalta district after passing the official exam at the Muftiate in Ufa, in $1874 .^{33}$ Looking back in 1920 , Mufti 'Alimdjan al-Barudi counted Bilal al-Din among the best scholars of the older generation in Kazan. ${ }^{34}$ While Bilal al-Din did not produce any scholarly works that would illustrate his Islamic erudition and views, ${ }^{35}$ his son Isma'il 'Abidi, to whom we will turn below, was certainly a very talented and well-educated young scholar; he authored several treatises in Tatar that he also managed to publish in the course of the 1910s. ${ }^{36}$ He penned journal articles in which he described the deplorable state of the contemporary Tatar nation, ${ }^{37}$ called for the spread of literacy via public lectures, ${ }^{38}$ and defended the moral status of the Muslim authorities against the caricatured depictions displayed on the theatre stage. ${ }^{39}$ Isma'il 'Abidi was an admirer of 'Abdullah Tuqay's romantic poetry: in his own manuscripts he often cited the verses that he admired, and he even composed a touching elegy (marthiyya) on the death of Tuqay in $1913 .^{40}$ 'Abidi regularly produced poetry, and left us with an unpublished collection of his verses. ${ }^{41}$ In general, from the available documentation, Isma'il comes across as a well-educated person with a deep interest in literature, ${ }^{42}$ a teacher who supported the rights of women, ${ }^{43}$ and a staunch nationalist, since most of his public prose dealt with the articulation of Tatar national interests (Figure 2).

elements of cultural geography peculiar to the local Muslim culture at least until the early twentieth century: Shihab al-Din al-Mardjani, Wafiyyat al-aslaf wa tahiyyat al-akhlaf, vol. 6, Kazan University Library, Ms. 614 Ar., ff. 64a, 66b, 96a, 137a (al-Jabali), 217a (Jabalistan).

33 The Vakhidi archive, Op. 5. D. 13, f. 20a.

34 Barudi 2018: 132.

35 The same surprising lack of scholarly accomplishments characterizes the written oeuvre of 'Alimdjan al-Barudi: he produced diaries and letters on a much greater scale than theological works, which mainly covered the basics of Islamic religion and were meant as textbooks for madrasa students.

36 'Abidi 1914, 1917.

37 Isma'il 'Abidi, Bezneng eshlär, Institute of Oriental Manuscripts (St Petersburg), Ms. D 480 (I), ff. $1 b-2 b$.

38 Isma'il 'Abidi, Kichke däreslär, Vakhidi archive, Op. 5. D. 9, f. 1a.

39 Isma‘il ‘Abidi, “Yäshä Zäbirä, yäshim min!” sähnädä quelu münäsäbätilä, Institute of Oriental Manuscripts (St Petersburg), Ms. D 480 (II), ff. 1b-5b.

40 Isma‘il 'Abidi, "Märhüm shagyir Tuqaif ruhïna”, Vakhidi archive, Op. 5. D. 13.

41 Isma'il 'Abidi, Iüräk zarlarï, Institute of Oriental Manuscripts (St Petersburg), Ms. B2685.

First mentioned in Dmitrieva 1980: 134.

42 Isma‘il 'Abidi, Ädäbiyat wä "näzariyat ädäbiya”, Vakhidi archive, Op. 5. D. 8, f. 4a.

43 Isma‘il 'Abidi, Islam näzarïnda khatïn-qüz, Vakhidi archive, Op. 5. D. 7, ff. 1a-2b. 


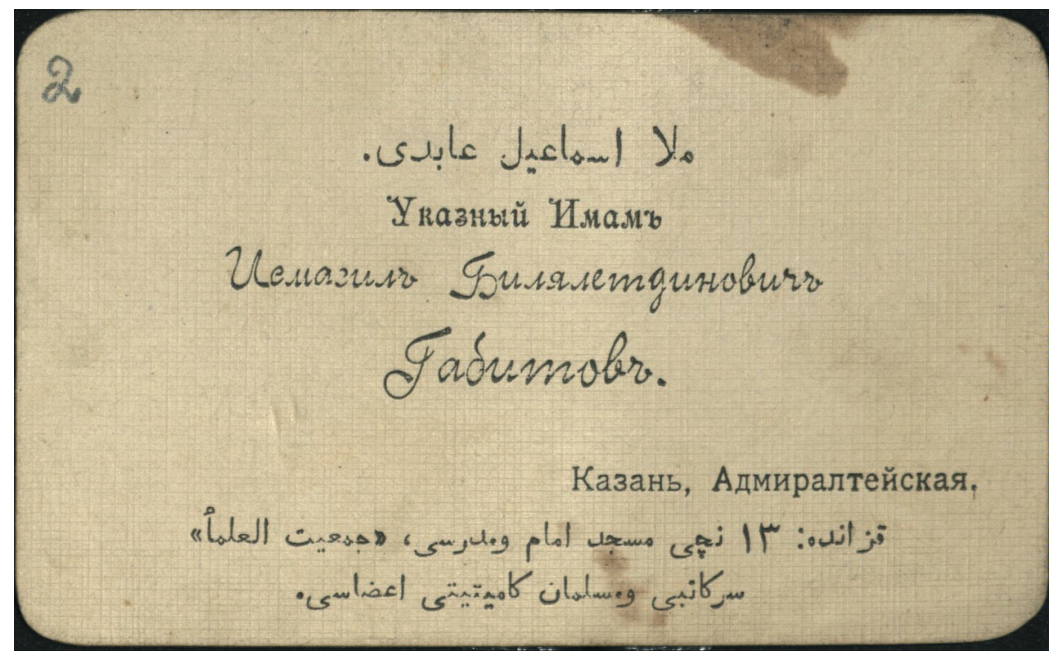

Figure 2: Isma'il 'Abidi's business card.

A bilingual inscription reads:

"Mullah Isma'il 'Abidi.

Licensed imam.

Ismagil Bilialetdinovich Gabitov

Kazan, Admiralteiskaia [street]

In Kazan: imam and teacher of the 13th mosque, secretary of the Scholarly Society and member of the Muslim Committee."

The Vakhidi archive, Op. 5. D. 10, f. 2 a.

Isma'il married soon after his return from his studies in Medina, in June 1915. Already in August 1916, together with his wife Zakiya, Isma'il 'Abidi opened a school for girls, located in his home district, with the express goal of maintaining the high status of women in Muslim society. ${ }^{44}$ It seems, however, that not everything was well in the new family: in April of the same year, rumors spread in Kazan of Isma'il's attempted suicide. His relatives speculated that the complicated relationship between his wife and his mother was the cause of the incident, ${ }^{45}$ a rather unexpected one for a member of Muslim elite. 'Abidi's personal papers contain no further hints of familial tensions, which in itself must reflect the emotional impact of this episode.

44 A protocol of the inaugural meeting of the school, penned by 'Abidi: Vakhidi archive, Op. 5. D. 4, f. 1a. Children were meant to learn religious ethics (dini ruh wä äkhlaqi tärbiya) and to be prepared for the study of literature and Arabic language. There was a library available for students. Teachers also provided classes on Tatar literature in the evenings, while in summer they offered excursions to historical sites in Kazan as well as a trip to the old city of Bulghar, some $200 \mathrm{~km}$ away.

45 Anonymous letter (April 15, 1916), the Vakhidi archive, Op. 5. D. 14, f. 34 a. 
In sum, what we know about 'Abidi seemingly portrays him as "yet another reformist" of the time. I believe, however, that moving beyond the narrative of Islamic reformism ${ }^{46}$ promises to yield much greater epistemic value.

Let us now look at a small body of correspondence that illustrates the history of the "Abidi family in late imperial Russia. This familial approach ${ }^{47}$ has been tested by Allen Frank, in his inspiring research on several generations of Muslim scholars in the Volga-Urals region, who had been in close contact with centers of education in Central Asia throughout the nineteenth and early twentieth centuries. ${ }^{48}$ On the basis of this information, Frank reconstructed the dynamics of educational and devotional practices of Tatar students in Central Asia and back home. Frank's monograph on the Muslim prestige of Bukhara clearly shows that members of the scholarly circles cared much about their familial histories and private documents, which they used extensively when writing local village histories, for instance. ${ }^{49}$ Socially speaking, what the archives offer are the writings of a middle-class clergy or rukhanilär, ${ }^{50}$ a group of people whose professional activity was linked to religious duties but who also fulfilled a wide range of literary, economic and political functions.

While Allen Frank has demonstrated the continuing prestige of Bukhara, 'Abidi's papers reveal a generational change in cultural orientation: while Bilal al-Din (the father) was a Bukharan student and regularly used Persian expressions ${ }^{51}$ for personal notes in his pocket-book (including the birthdates of his children and other important family events), his son Isma'il was clearly under the Ottoman influence - in his poetry he praised the Ottoman army generals ${ }^{52}$ - and definitely preferred Arabic over Persian. In most documentation that has survived, we find Isma'il 'Abidi outside of Russia: first on his educational trip to Mecca and Medina in 1910-1912, and later in revolutionary Central Asia, were he pursued the goal of building a new social order. This case thus provides a good opportunity to look at Muslim personhood in a trans-imperial urban setting.

46 DeWeese 2016: 37-92.

47 On the foundational significance of familial relationships for subjectivity see Roper 2005: 67.

48 Frank 2012.

49 On the genre of village histories see2001: 21-29; Shaikhiev 1990.

50 This term seems to appear first at the turn of the nineteenth century and reveal a strong Christian influence with a meaning of "spiritual fathers", not part of the vernacular of the Muslim societies. Cf. Naganawa 2007b: 80-81.

51 On the relevance of Persian literacy among the Muslims of Russia see Bustanov 2019a: 193206. 'Alimdjan al-Barudi's personal notebook from his student times in Bukhara bears texts exclusively in Persian.

52 Isma'il 'Abidi, Yüräk zarlarï, Institute of Oriental Manuscripts (St Petersburg), Ms. B2685, ff. 5ab. 


\section{The flow of correspondence}

The small collection of Isma'il 'Abidi's private correspondences survived in the archival files of a prominent Tatar historian and book collector, Said Vakhidi (1887-1938), ${ }^{53}$ and were subsequently described by Zainap Maksudova (18971980)..$^{54}$ Most probably, these letters found their way into the library of Vakhidi soon after Isma'il 'Abidi was imprisoned in the early 1930s, shortly before the same fate befell Vakhidi himself, in 1938. As Vakhidi's large collection was split into several parts, some of 'Abidi's papers found their way into the Institute of Oriental Manuscripts in St Petersburg, while the largest part remains in Kazan, in today's Institute of Language, Literature and Art of the Academy of Sciences of the Republic of Tatarstan. ${ }^{55}$

Besides his prose and poetry, about one hundred letters and postcards addressed to Isma'il 'Abidi, or written by him or his father, Bilal al-Din, have also survived to this day. The bigger picture of this correspondence led by one person can be understood thanks to a small notebook (kuen däftäre) that Isma'il 'Abidi kept about his regular letter exchange, ${ }^{56}$ which covers the short period between 1910 and 1912. Composition of such notebooks was a common practice at that time. ${ }^{57}$ Bilal alDin filled a notebook of his own and later his son Isma'il adopted the practice of his father. In the first part of the notebook 'Abidi recorded the letters that he wrote himself, while in another part of the notebook he kept a list of incoming correspondence. Unfortunately, only a few letters mentioned in the document have actually survived. In what follows, I will try to draw on these two types of source: the letters that survived, and the description of daily correspondence.

The notebook reflects 'Abidi's correspondence while he was on his way to the holy places of Mecca and Medina, ${ }^{58}$ as well as his stay in a Tatar madrasa in Medina

53 On him see Gumerov 2017.

54 Bustanov 2018: 1-31, Bustanov 2019b.

55 Description of the latter is available online: http://miras.info/resources/funds/30-vahidovsaid-gabdulmannanovich.html (last accessed May 29, 2019).

56 The Vakhidi archive, Op. 5, D. 15, ff. 2a-9a.

57 A notebook by Badi` Husainov al-Qazani, mu'adhdhin of the White Mosque in Kazan (led by 'Alimdjan al-Barudi), and his daughter Fahima, composed between 1900 and 1910, Institute of Oriental Studies (St Petersburg), B 2537. Initially the book owner noted data on the rental of his property in Kazan (ff. 1b-4a), but soon, similar to 'Abidis' notebooks, he used this form of writing to document the letter exchange with his son Muhammad Rafi' who studied in Egypt between 1902 and 1908 (a note on his long-awaited return belongs to Fahima, his younger sister: f. 44a). Another file full of his personal notes is located in Kazan University Library, Ms. 594 T, 25 f.: “Bädig mäzin el'yazmasi””. In Gainetdinov 2014: 316-325.

58 On hajj from the Russian Empire see Kane 2015; Sibgatullina 2010, chapters 1 and 2. 
starting from January 1, 1911. From September to December 1910, 'Abidi penned sixteen letters. Ten of them were sent to his parents (ätkäyläremä; wälidäynemä), five he sent to a brother-in-law in Challï village (zhizni), and a single letter to a certain Karim makhdum in Bukhara. All letters are divided into open (achïq) and enveloped (yabïq), referring to postcards and regular letters in envelopes, respectively. Each letter bears a number to preserve the sequence of his written communication, because letters could get lost or arrive at different times. This diligent book-keeping of his personal correspondence reveals the pride that Isma'il took in his networking activity, and the emotional value he attached to it.

In general, the idea of a flow of correspondence occupies an important place in the contents of the letters. Usually, the letter-writer starts with a long list of greetings to the closest acquaintances, including relatives and even neighbors of the addressee ${ }^{59}$; then the writer reports that he/she has received the previous letter of the recipient, replying in short to the main message conveyed there: "as I also wrote to you in my previous letter” (muqaddäm mäktübemdä dä yazgan idem). ${ }^{60}$ The repetition of formulas like these create the impression of a communicative continuum that reflects strong social ties. The continuity of the conversation over time, and over space, is also obvious from notes about when the addressee posted this or that letter: “On 26 December [18]92 letters to Semipalatinsk ${ }^{61}$ and Troitsk were sent. [...] In the first days of 1893 my son Sangatullah went to Semipalatinsk. May God return him safely. On July 22 I sent a letter to Semipalatinsk." 62 This practice of documenting letter exchange can be explained not only by archival pragmatics, but also by the degree of historical consciousness and emotional attachment to correspondence with close acquaintances. Keeping a record of letter communication thus ends up being a type of archival practice ${ }^{63}$ that reflects the individual's very identity. Not only the content of letters, but also their outer appearance - as well as the record of their flow and their forms of preservation - are all factors reflecting individualized experience as preserved in artifacts.

Let us start our analysis by grouping the data found in 'Abidi's notebook: Some of the letters arrived via the state postal system, for which one had to pay. In other cases, they were carried by individuals: on November 15, 1910, a certain

59 "Greetings to our neighbors 'Arif and 'Abdullah abzz̈y, whom I ask to pray for me." Vakhidi archive, Op. 5. D. 13, f. 4a (July 18, 1911).

60 Vakhidi archive. Op. 5. D. 13, f. 4b (July 18, 1911).

61 In the original: Semey.

62 Institute of Oriental Manuscripts (St Petersburg), A1179, f. 8b. This is a notebook of Lutfullah Sulaymanov, acquired by a 1934 manuscript expedition under the auspices of the Soviet Academy of Sciences (and led by Vakhidi).

63 Pickett/Sartori 2019. 
Yusuf äfendi brought Isma'il a letter from a brother-in-law in Challï, and on January 1, 1911 a person named Qawam qari went to Kazan with a letter that 'Abidi wrote to his parents. In 1911, Isma'il, at that time in Medina, retrieved letters from Russia for Taqi äfendi, who at that time was in Mecca. Thus various forms and strategies of communication were available at the same time: official and private networks of communication coexisted, leaving individuals the freedom to decide which way was preferable.

From the data offered in Table 1, we see that on his way to the holy places, Isma'il 'Abidi kept a stable connection only with his parents and a brother-inlaw. After stopping in Mecca and then settling in Medina, the number of his addressees grew, but the intensity of communication with people back in Russia and in the Near East remained low. This can be attributed to two reasons. First, sending letters abroad was a costly and time-consuming activity (in 1910 it took a month for a letter to travel from Mecca to Bishbalta district in Kazan ${ }^{64}$ ). Secondly, as 'Abidi was still a young student, he did not yet have a large network of contacts; his relations in Russia were most probably restricted to his family and fellow students, which would explain why the geographical scope of his correspondence was not yet impressive. ${ }^{65}$

Parents usually preserve the letters they obtain from their children, much more than the children pay attention to the writings of their parents; but later on, it is the offspring that inherits these collections, including their own letters. Previously, these letters had been of emotional value for elders back home, but when they passed away, the same items became precious objects of emotion ${ }^{66}$ for their children, reminding them of their relationships with their parents. ${ }^{67}$ This is also reflected in our case study: none of the letters addressed to Isma'il have survived; we only have what he wrote to others.

We should also keep in mind that the field of letter-writing was dominated by men. Letters penned by female members of Muslim society are rare among

64 The Vakhidi archive, Op. 3. D. 13, f. 25a (a letter to parents dated December 10, 1910).

65 Especially when compared to those individuals who communicated with hundreds of people a year; an example is Kamal Muzaffari (1855-1937?), a rich merchant and antiquarian from Malmyzh in Viatka governorate. Kazan University Library, F. 6. Albert Fathi. D. 94. Kamal Muzaffari, ff. 2-78 (a list of archival items with the personal letters that he received in the 1910s). 66 Downes/Holloway/Randles 2018; Scheer 2012.

$67 \mathrm{Cf}$. a series of notes on the copy of a legal compendium Sharh 'Abd al-Haqq, inherited in the trading family of Utiamishevs: first it was acquired by Musa b. 'Abd Allah al-Machkarawi in 1236/ 1820, then inherited by his son Badr al-Din, and in 1871 moved into the hands of Bibi 'Aisha b. Ahmad Shah al-Machkarawi as part of the inheritance from her brother Muhammadjan: Kazan University Library, Ms. 751 F, f. 1a. 
Table 1: Isma‘il 'Abidi’s correspondence notebook.

\begin{tabular}{|c|c|c|c|c|}
\hline Writer & Addressee & $\begin{array}{l}\text { Number } \\
\text { of letters }\end{array}$ & Place of departure & Titulary \\
\hline \multicolumn{5}{|c|}{ September - December 1910} \\
\hline Parents $^{\mathrm{a}}$ & Isma'il 'Abidi & 4 & Kazan (Bishbalta) & \\
\hline Isma‘il ‘Abidi & Parents & 10 & $\begin{array}{l}\text { Nizhnii, Moscow, } \\
\text { Kharkov, } \\
\text { Sevastopol, } \\
\text { Odessa, Istanbul, } \\
\text { Mecca }\end{array}$ & \\
\hline Ibrahim & Isma‘il ‘Abidi & 1 & Challï & Zhizni \\
\hline Isma‘il ‘Abidi & Ibrahim & 5 & $\begin{array}{l}\text { Sevastopol, } \\
\text { Istanbul, Mecca }\end{array}$ & \\
\hline Karim & Isma‘il 'Abidi & 0 & Bukhara & makhdum \\
\hline Isma‘il ‘Abidi & Karim & 1 & Mecca & \\
\hline
\end{tabular}

\begin{tabular}{|c|c|c|c|c|}
\hline \multicolumn{5}{|c|}{ January - October 1911} \\
\hline parents & Isma'il 'Abidi & 21 & Kazan (Bishbalta) & \\
\hline Isma‘il ‘Abidi & Parents & 21 & Medina & \\
\hline Ibrahim & Isma‘il ‘Abidi & 12 & $\begin{array}{l}\text { Challï } \\
\text { Kazan }\end{array}$ & zhizni \\
\hline Isma'il 'Abidi & Brother-in-law & 12 & Medina & \\
\hline ‘Abd al-Bari & Isma‘il ‘Abidi & 0 & $?$ & arqadash \\
\hline Isma'il ‘Abidi & 'Abd al-Bari & 2 & Medina & \\
\hline Khwajajan & Isma'il ‘Abidi & 0 & Baltach & abïy \\
\hline Isma‘il ‘Abidi & Khwajajan & 2 & Medina & \\
\hline 'Abd al-Rahman Rafiqi & Isma'il ‘Abidi & 4 & $?$ & ostazïm \\
\hline Isma‘il ‘Abidi & ‘Abd al-Rahman Rafiqi & 3 & Medina & \\
\hline Badigel (?) & Isma‘il ‘Abidi & 0 & $?$ & apa \\
\hline Isma‘il ‘Abidi & Badigel (?) & 1 & Medina & \\
\hline Grandfather & Isma'il 'Abidi & 1 & Suïqsu & däüätilär \\
\hline Isma‘il ‘Abidi & Grandfather & 3 & Medina & \\
\hline Sibgatullah & Isma'il 'Abidi & 0 & $?$ & ostazïm \\
\hline Isma‘il ‘Abidi & Sibgatullah & 1 & Medina & \\
\hline Karim & Isma'il ‘Abidi & 2 & Bukhara & makhdum \\
\hline Isma‘il ‘Abidi & Karim & 1 & Medina & \\
\hline 'Abdullah al-Amirkhani & Isma'il 'Abidi & 0 & $?$ & häzrät \\
\hline Isma‘il ‘Abidi & $\begin{array}{l}\text { 'Abdullah } \\
\text { al-Amirkhani }\end{array}$ & 1 & Medina & \\
\hline 'Abdullah & Isma'il 'Abidi & 1 & Usa & abïy \\
\hline Isma‘il 'Abidi & ‘Abdullah & 1 & Medina & \\
\hline Isma‘il Yusuf & Isma'il ‘Abidi & 0 & Istanbul & \\
\hline
\end{tabular}


Table 1: (continued)

\begin{tabular}{|c|c|c|c|c|}
\hline Writer & Addressee & $\begin{array}{r}\text { Number } \\
\text { of letters }\end{array}$ & Place of departure & Titulary \\
\hline Isma‘il ‘Abidi & Isma‘il Yusuf & 1 & Medina & \\
\hline Muhammad Najip & Isma‘il 'Abidi & 2 & $?$ & makhdum \\
\hline Isma'il 'Abidi & Muhammad Najip & 1 & Medina & \\
\hline Isma‘il Muskin & Isma‘il ‘Abidi & 3 & $\begin{array}{l}\text { Istanbul } \\
\text { Beirut }\end{array}$ & \\
\hline Isma'il ‘Abidi & Isma‘il Muskin & 1 & Medina & \\
\hline Taqi & Isma'il 'Abidi & 1 & Beirut & äfendi \\
\hline Isma‘il ‘Abidi & Taqi & 1 & $\begin{array}{l}\text { From Medina to } \\
\text { Mecca }\end{array}$ & \\
\hline Ibrahim Amirkhan & Isma'il 'Abidi & 1 & Beirut & \\
\hline ‘Ali Riza & Isma'il 'Abidi & 1 & $?$ & \\
\hline Nurullah & Isma‘il ‘Abidi & 1 & ? & abïy \\
\hline
\end{tabular}

${ }^{\mathrm{a}}$ The order of writers follows that of the manuscript.

the sources that I know. As one elderly lady confessed to her children in Kazan in a letter, she did not write much during the year, and hence left it to readers to correct the possible orthographic mistakes arising from her lack of practice. Journalist Karim Sagitov (1888-1939), who produced the academic description of her letter stored in the collection of the Leningrad Institute of Oriental Studies in 1934, was quick to recognize "female handwriting" (khatïn-qïz quli belän yazilgan). ${ }^{68}$ Most probably, married women either exchanged letters only with members of the same gender, ${ }^{69}$ or participated in letter production via the correspondence of men, as I will demonstrate below. This is, of course, not to say that Muslim women lacked the education to write letters - on the contrary. ${ }^{70}$

68 An undated letter from the wife of Ahmad-Shuja، al-Sharifi to her son-in-law, daughter and grandson: Institute of Oriental Manuscripts (St Petersburg), B3502, f. 6a. Description of the letter is attached to this archival file. On Karim Sagitov, see a short biographical note in a dictionary of repressed Soviet Orientalists: http://memory.pvost.org/pages/sagidov.html (last accessed on March 7, 2018).

69 For example, a letter from Sahipjämal Gafarova to Hadidja bikä (September 26, 1916): Kazan University Library, $1190 \mathrm{~T}$.

70 Frank 2001: 224-226. A wonderful example of female literacy is a collection of autobiographic poetry compiled near Astrakhan by Gazizä Sämitova (1862-1929): Institute of Oriental Manuscripts (St Petersburg), Ms. B4106. An abridged publication in modern Tatar (Sämitova 1965). Another collection of commemoratory poetry (marthiyya), collected by 'Afifa al-Tuntari, was presented (hidiyä qilib) to her son Muhammad Najip al-Tuntari (d. 1930), for whom this was an object of great emotional value (Kazan University Library, Ms. 247T, notes on the front page). 
Rather, in written communication, it was accepted practice that the voice of women was subjugated to that of male actors. ${ }^{71}$

We do not have letters written by Bilal al-Din to his son Isma'il, but their letter exchange between 1910 and 1911 is documented in the father's notebook. These registers tell us something about the technicalities of correspondence. In the beginning, the father wrote to Mecca via Tatar intermediaries ${ }^{72}$ who had residence in Mecca: "To 'Abd al-Rahman b. 'Abdullah and damadi Ahmad Shükür äfendelär from Kazan, the residents of Mecca the Honored opposite Bab al-Salam. To be delivered to Isma'il "Abidi." "73 And when Isma'il moved to Medina, Bilal al-Din sent his letters to the new addresses:

Address: Medina the Radiant, to Isma'il makhdum.

In the city of Medina in Arabia, via Odessa. ${ }^{74}$

To be delivered from Kazan to Isma'il makhdum 'Abidi äfendi, a student residing at Qazanlï madrasa via Husayn äfendi, an imam of Qazanlï mosque in Medina the Radiant.

[...]

A list of letters sent to Isma'il hajji makhdum in Medina the Radiant:

On Wednesday 8 June I sent a letter (khat) to my son Isma'il hajji to Medina the Radiant.

On 31 May I received a letter written on 10 May. On the same day I sent a letter to Sa'di. ${ }^{75}$

On Wednesday 15 June I sent a letter to Medina the Radiant.

On Monday 27 June I sent a letter to Isma'il hajji in Medina the Radiant.

On Monday 4 July I again sent a letter to Isma'il hajji.

I received a letter from Medina the Radiant on Tuesday 5 July.

On Wednesday 6 July I sent a letter and 50 kopeks (tänkä) ${ }^{76}$ with 'Abd alRahman Mamashev.

71 For further reading on Muslim female authority in Russia see Kefeli 2014: 139-160.

72 On functions of intermediaries and their difference from couriers see Sood 2009: 1090.

73 A notebook of Bilal al-Din al-'Abidi, Institute of Oriental Manuscripts (St Petersburg), Ms. B2561, f. 36b. This is a thick notebook in the original referred to as raznosnaia kniga, filled by Bilal al-Din al-'Abidi and occasionally by his son Isma'il between 1900 and 1910s. The manuscript survived in the collection of books donated by Said Vakhidi.

74 This phrase is written in Russian: “Въ г. Медину въ Аравии через Одессу.”

75 Sa'di or Sa'd al-Din 'Abidi appears to be a relative of Bilal al-Din, who worked as a soapmaker in Sterlitamak in the Ufa governorate: A notebook of Bilal al-Din al-'Abidi, Institute of Oriental Manuscripts (St Petersburg), Ms. B2561, f. 37a.

76 Sending money by post or with a courier was a regular practice, routinely mentioned in private letters. For example: Vakhidi archive, Op. 5. D. 13, f. 20a (1915). 
I wrote an answer to a letter received on 5 July and took it to a post office (pushta) $^{77}$ on Monday 11 July. ${ }^{78}$

This list shows the intensity of communication as well as its embedding in existing institutions and religious, economic, and educational networks. Letter exchange, as we shall see, was directly linked to the hajj route via Odessa, which in turn was also a path to the important educational centers in the Middle East, i. e. Medina, Damascus, Cairo, and Istanbul. We know that Muslim students from Russia who went to study in Central Asia combined their educational activities with pilgrimage practices, trade, and letter exchange, ${ }^{79}$ and we can assume that Tatars in the Middle East did the same. Moreover, we observe that the dietary preferences of the young students from Russia reveal habits acquired in Central Asia: in letters to his parents, Isma'il stresses that the hot climate of Mecca and Medina makes it impossible to eat pilaf prepared by classmates in the Bukharan fashion. ${ }^{80}$ In Medina, Isma'il stayed with two other persons, most probably of his age: Qawam makhdum - the son of a respected damullah Husam al-Din häzrät, and Taqi äfendi - the son of an imam in Bäräzä village near Kazan. The latter was a close friend of Isma'il, with whom he also corresponded when they parted in fall 1911.

In the absence of any other means of communication, a stable flow of correspondence was crucial. When letters stopped coming, the students started to worry, and thought about returning home as soon as possible: "Qawam makhdum has not received a letter for more than twelve months. Really nothing. He is thinking about returning to our land (mämläkät) ${ }^{81}$ after this hajj [season]." ${ }^{82}$ Years later, while in

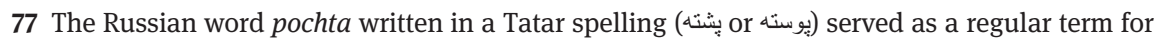
describing the state postal system. The usage of this term is juxtaposed with the personal networks of exchange within Muslim communities. Cf. letters penned by Mahmud al-Almali with the same word usage: Kazan University Library, Ms. 1TGF, f. 63a, which also reflects a common usage of the word in Daghestan.

78 A notebook of Bilal al-Din al-'Abidi, Institute of Oriental Manuscripts (St Petersburg), Ms. B2561, ff. 21a, 37b.

79 For example, in 1829 on his way to Mecca a Tatar pilgrim from Bashkiria first went to Khorezm, where he spent eight months at a Sufi lodge: 'Abd al-Qadir al-Bulghari, al-Risala alBulghariyya fi sabil al-hajj, Kazan University Library, Ms. 5959 T, ff. 1b-2a. Cf. Naganawa 2012a: 168-198.

80 Cf. Frank 2012: 74.

81 Mämläkät is a category for denoting a Muslim fatherland. For example, it appears in the subtitle of Riza Fakhretdin's biographical dictionary: "Biographies of Muslim Scholars of our Country (üz mämläkätemezdä).” Even nowadays, the Tatar migrants in Turkey routinely refer to their homeland in Russia as mämläkät, which does not correspond with any political or administrative entities, which have dramatically changed over time.

82 The Vakhidi archive, Op. 5. D. 13, f. 4a (July 18, 1911). 
Tashkent, Isma'il asked his relatives at home to read aloud a fragment of his letter to his younger sister, Bibi Sarä: "My darling Sarä! You do not write me a letter, even a single letter! Is this appropriate? No, you should not be like that."83

The language used in communication clearly depended on the type of relationship between correspondents, and on the evolution of personal values and preferences. For example, Isma'il's letters to his parents reveal strong Ottoman influences in language use. In September 1910, while still on his way from Russia to the Holy Lands, he regularly uses Ottoman words and grammatical forms. "Heat" is not esselek, but sïaqliq, while "they" is rendered by onlar and not alar. ${ }^{84}$ One could legitimately disregard these features given the general popularity of Ottoman forms in the literary Tatar language at the turn of the century; in this case, however, the Ottomanism arises only as a situational practice, reflecting Isma'il's mood in sending a letter from Istanbul, and not a general shift in his language use.

In almost every letter to his loved ones back home, Isma'il writes how he misses his relatives, how he loves them and hopes to see them in the very near future. This personal attachment also defines his choice of words when addressing these relatives: "The light of my eyes and the sun of my heart" (nur-i 'ayni wa khurshid-i qalbi). ${ }^{85}$

However brief, insignificant and fragmented the contents of Isma'il's letters might appear at first glance, what unites all the individual items are the vivid and emotional passages of text. One of the letters in particular stands out for its emotional appeal. Back in Kazan in September 1913, Isma'il wrote to a close friend of his, Fath al-Bayan, whom he usually addressed without adding a honorific title. The whole letter consists of damning the unjust behavior and immorality (insafsïzliq-wijdansïzlï) of two persons named Thabit and Hamid, who took money on trust (bädäl, possibly referring to money to perform the hajj for somebody) from the Bishbalta community (mähällä) and refused to give it back. Isma'il exclaims: "I knew the dirty tricks of Thabit already in Medina, but did not think that he would do such [wicked thing]." ${ }^{\text {"6 }}$ It was not the money itself that triggered strong feelings in Isma'il, but rather the fact that fellow students committed such a shameless act of injustice.

83 The Vakhidi archive, Op. 5. D. 13, f. 24b (May 2, 1917).

84 The Vakhidi archive, Op. 5. D. 13, f. 2ab (September 29, 1910).

85 The Vakhidi archive, Op. 5. D. 13, f. 4b (July 18, 1911). Cf. Mahmud al-Almali in his letters called one of his closest disciples "light of my eyes" (nur-i chashmi).

86 The Vakhidi archive, Op. 5. D. 13, f. 8b (September 14, 1913). The last word here is not written in full in the manuscript, but rendered as خذ..., which might be read as an abrogation of obscenity. 


\section{A new scholarly persona}

The early $20^{\text {th }}$ century witnessed an emergence of a new type of scholarly persona among Russia's Muslims, i. e. "models (real or imaginary) that [scholars] believe to embody habits, virtues, skills or competencies required for being a good scholar." ${ }^{\text {"P }}$ Previous models had been largely associated with Persianate culture and assimilated by Muslim students in Central Asia. The educational shift towards the Middle East at the turn of the century brought with it a paradigmatic change in ideas of how a proper Muslim scholar should look. The differences in selfexpression between Bilal al-Din and Isma'il 'Abidi exactly reflect this shift.

The earlier style of persona was familiar to the son. From Isma'il's letters, it is clear that before he embarked upon a trip to Arabia he had studied with local teachers in Russia. Their names are briefly mentioned in the register of Isma'il's letters reproduced in Table 1 - 'Abd al-Rahman al-Rafiqi and Sibgatullah. However, their identity and origins remain unknown. We do not know when Isma'il first went abroad, but from available documents we see him traveling from Kazan via Samara in October 1908. In March of the following year, a certain 'Abdullah Amirkhan from Kazan's Bishbalta district wrote to Isma'il advising him to stay "there" - wherever he was at that time - rather than to return to Kazan for a summer vacation: "It is better to save money and study Qur'an commentary and prophetic traditions. The longer you stay, the higher your esteem will be (qaderengez). Knowledge and enlightenment (gïylem vä mägrifät) are the most important things." ${ }^{88}$ The place where Isma'il studied at the time is unknown, but given the fact that in later years he described his life in Mecca and Medina with much excitement as something that was new to him, he must have been elsewhere when he received that advice, possibly in Istanbul.

'Abdullah Amirkhan's recommendation notwithstanding, at some point young Isma'il returned to Kazan; and in September 1910, he performed his trip to Arabia. Upon arrival in Mecca, Isma'il was not sure where to study and therefore asked around. There was a Tatar madrasa in Medina known as Qazaniyya or Qazanli, which he must have heard of back at home, but its reputation among students was not very high: "At the madrasa they only teach Quduri in law, Kafiya in grammar and a single Qur'an commentary. People say [süyliylär] that they do not like it if you take classes from other madrasas. Let us see how it is on the ground." ${ }^{89}$ A Tatar pilgrim of the same period describes the notorious rules of this madrasa in a similar way:

87 Paul 2019: 6. Cf. Algazi 2016.

88 The Vakhidi archive, Op. 5. D. 14, f. 5 ab (March 28, 1909), f. 7a (October 22, 1908).

89 Ibid., f. 25a (December 10, 1910). 
[Tatars] built a madrasa in Medina, called Qazanlï, and established the ranks of imam, mu'adhdhin, servant, and water carrier; and they bought many buildings to support students there. In total, up to fifteen buildings [belong to the madrasa]. However, each of them has been appropriated by the imam, the mu'adhdhin, the shaykh and his companions and relatives. All of these people live in those buildings. Students get nothing of it. Moreover, other buildings are far away from the city and nobody rents them, they are useless. There is also a strict rule: students at the madrasa should not follow the courses of other respectable teachers. Otherwise the student will be expelled. Such a student will not be able to enter another madrasa, because they will tell him: 'You have to study at the Qazanlii madrasa.' Sometimes the students from Russia come to Qazanlï with such an amount of knowledge that it makes the teacher nervous. People say that the students spend four months studying the book Mishkat al-masabih, but what is the use of such superficial reading? In other classes, they study al-Hidaya, to which they turn only briefly. Sometimes it is possible to follow the classes in the mosque of the Prophet. They also study the books of Multaq al-abhar, [and] Mawlawi Jami. I asked them: 'For how long have you been studying this?' They answered: 'For eight years.' This struck me. If you tell them [i.e. the Tatar students who study there], they start hating you. They portray their shortcomings as their superiority and do not allow professionals to teach them. If someone goes to authoritative people, they see this as a sign of ignorance. This madrasa is thus worthless. Moreover, to make the situation even worse, there are countless conflicts among them. This is the state of our Tatar migrants, may God change it and open the right path. ${ }^{90}$

If learning in Medina posed issues for the Tatar students, why not go to Bukhara, as their fathers had? Or simply stay in Kazan with its twelve urban madrasas that had been established by $1905 ?^{91}$ In the early twentieth century, we witness a gradual decline of scholarly prestige of Bukhara among the Muslim students from Russia, ${ }^{92}$ and hence the emergence of a new type of scholarly persona, defined by nationalism, mastery of Arabic at the expense of Persian, attention to hadith scholarship, the study of the Qur'an, and social activism. Many young people sought to acquire the necessary skills in the Ottoman Empire, which became relatively safer and more accessible due to the new railway system and steamboats. ${ }^{93}$

To verify the rumors about the Qazanlï madrasa, Isma'il decided to travel from Mecca to Medina. The plan was to go in a group of five, namely with the above-mentioned Qawam makhdum, a certain Isma'il from Tetush city, a Naqshbandi shaykh from Orsk ${ }^{94}$ by the name of 'Abdullah al-Mu'adhi, and a

90 Khamidulla Al'mushev, Khadzh-name. Kniga o khadzhe. Putevye zametki / trans. by Azat Akhunov (Nizhnii Novgorod, 2006), f. 39 of the manuscript original.

91 Ross 2015: 65.

92 Frank 2012: 151-180.

93 Ozyuksel 2014. This is not to say, of course, that before the late $19^{\text {th }}$ century students from the Russian empire did not go to study in Cairo or Damascus, but it was on a different scale. 94 'Abdullah b. Muhammad 'Arif al-Mu'adhi (b. 1871/72) was an imam of the third mosque in the city of Orsk, an author of a series of historical and religious books. The reason why he did 
Mishar ${ }^{95}$ from Penza governorate. Except for al-Mu'adhi, all wanted to stay in Medina to study. ${ }^{96}$ Before setting off for Medina, Isma'il informed his parents about the dangers of a seemingly short trip. Bedouins used to attack caravans that circulated between Mecca and Medina, and many people lost their lives on the way. It seems that Isma'il was seriously worried, and not for nothing. At some point he even thought it might be better to stay in Mecca, as the trip promised to be expensive and mortally dangerous. ${ }^{97}$

After nine days, on December 27, 1910, ${ }^{98}$ the group of Russian Muslims arrived in Medina. The city appeared to be "a thousand times more beautiful than Mecca”, full of gardens, students and scholars. Having arrived there, Isma'il became very optimistic about studying at the Qazanli, headed by Mansur mudarris, probably the shaykh who appropriated most of the houses. Isma'il saw that other Tatar students had just enrolled at this school, including Naqib makhdum Tuntari, ${ }^{99}$ Rahim äfendi, the son of Sanghat mu'adhdhin from Kazan, and another three students from Mecca. Thus he became a student of Qazanli. Isma'il wrote to his father that there were professional reciters of the Qur'an (qari) and scribes who taught them how to write in thulth style. ${ }^{100}$ He does not make any mention of the possibility to enter the Sufi path in the region - which is remarkable, given the Sufi credentials of his father and that Sufi licenses from the Hijaz, with their global flair, were still highly fashionable in the Volga-Urals. ${ }^{101}$ A conscious rejection of Sufism thus became part of the new scholarly persona that Isma'il 'Abidi had chosen for himself. He was not alone; Isma'il related in a letter to his father that there was no place left at the madrasas: "This year a lot of students

not join others in studying in Medina was that he was on a regular hajj journey between October 1910 and February 1911. Al-Mu'adhi was still alive in February 1915, when he confirmed in a letter to Isma'il 'Abidi that he had received his book: the Vakhidi archive, Op. 5. D. 14, f. 23a. 95 The ethnonym mishar refers to the groups of Tatars primarily residing westwards from the Volga River.

96 The Vakhidi archive, Op. 5. D. 13, f. 25a (December 10, 1910).

97 After the trip, Isma'il wrote a short novel describing his fears on the road to Medina: Garabstan khätiräse (Karavan yulïnda), Institute of Oriental Manuscripts (St Petersburg), Ms. B2655, ff. 5b-8a. This is an undated manuscript from the collection of books donated by Said Vakhidi.

98 These dates are provided in Christian calendar in al-Mu'adhi's travel account: 'Abdullah b. Muhammad 'Arif b. al-Shaykh Mu'adh al-Uri, Rihla ibn al-Mu'adh ila al-Hijaz (Orenburg, 1913), 18.

99 Muhammad-Naqib al-Tuntari was the oldest son of the famous Ishmi Ishan (1842-1919), who, after studying in Bukhara and Samarkand, went to Medina in 1910.

100 The Vakhidi archive, Op. 5. D. 13, f. 38a (January 1, 1910).

101 On the importance of Near Eastern Sufi ijazas to Daghestan and Tatarstan at the turn of the $20^{\text {th }}$ century see Shikhaliev/Kemper 2017: 166-198. 
came [to study]. [...] In total there are more than one hundred Tatar students.”"102

Contrary to what might be expected from a student new to the Arab cultural setting, he devotes almost no space to ethnographic description of what he saw. Despite the surrounding international environment, non-Tatars are completely absent among the recipients of his letters. Even at such great distance from his homeland, 'Abidi tried to keep closer to the fellow members of his community, with whom he shared a language and country of origin. This inclination, however, did not diminish his desire to learn the language from Arabs in Mecca: "My intention is to approach the same Arab teacher with whom Qawam makhdum had studied, because if you do not study with Arabs, it is impossible to master Arabic." 103 From this quote we get the impression that, generally speaking, learning Arabic was one of the main goals of Isma'il in his trip to Medina.

People whom we might recognize as outstanding historical figures of Russia's Islam also regularly appear in the pages of Isma'il's letters. Their appearance is incidental; the communication was certainly not centered on great names, or their words and deeds. In general, purposeful descriptions of another's individuality are extremely rare in Isma'il's correspondence. In summer 1911, 'Abidi decided to continue his stay in Medina, because he wanted to study with Muhammad Murad häzrät. ${ }^{104}$ Most probably he was referring to a renowned specialist in Islamic sciences, Muhammad Murad al-Ramzi (18551934), a native of Ufa governorate, who from the 1870s traveled widely in the Middle East and Central Asia and spent many years in Medina. ${ }^{105}$

Isma'il 'Abidi did not stay in Medina for long: already in summer 1912 he received a license from the Muslim Spiritual Assembly to perform the duties of imam in his native Bishbalta district in Kazan. The same year, his friend Taqi äfendi also acquired a diploma after passing an exam in Ufa. ${ }^{106}$ For Isma'il this educational trip was exciting and useful, but certainly he did not consider staying abroad for a long time, simply because he saw more opportunities in Russia. When back in Kazan, he tried to encourage his close friend Fath alBayan to come back from Medina: "Please come back! Do not stay there."107 A year later Isma'il exclaimed:

102 The Vakhidi archive, Op. 5. D. 13, f. 38a (January 1, 1911).

103 The Vakhidi archive, Op. 5. D. 13, f. 25a (December 10, 1910).

104 The Vakhidi archive, Op. 5. D. 13, f. 4a (July 18, 1911).

105 Aykut 2015.

106 A notebook of Bilal al-Din al-'Abidi, Institute of Oriental Manuscripts (St Petersburg), B2561, f. 66b.

107 The Vakhidi archive, Op. 5. D. 13, f. 12a (September 14, 1913). 
In your letter you write that you have decided not to come back. Did you become a buffoon there? What does it mean? For how long are you planning to stay there? Until the Day of Judgement? Ha! If so, very good. Of course, Hijaz and the Sacred Land are honorable and great, but still there is no reason to smell its greatness and grace until one's death. In this regard I am really amazed by Känz äfendi, because if he had returned to Russia, he would have been taken [for a job] immediately. [...] Taqi äfendi has just come back. In addition to his regular job he went to teach Qur'an commentary to girls in Ufa and earned another two hundred rubles. Think about it, this is a salary of seven-and-a-half months! ${ }^{108}$

This is a brilliant manifestation of pragmatic concerns that guided this type of scholar: yes, Medina is a great place of piety, but one has to be quick to take opportunities without wasting time. It is not surprising, therefore, that the Russian Revolution brought the ambitious Isma'il to Tashkent: here, he was busy creating the new societal order and only his mother's letter made him go back. "I simply cannot leave our business unfinished; but, however great the merit of nation is, the merit of mother is always greater," wrote Isma'il disappointedly after securing his tickets home. ${ }^{109}$

\section{On models and subjectivity}

Isma'il 'Abidi, like many of his contemporaries, had access to a wide cultural repertoire when it came to communicative practices: the use of the official postal system or private networks, the Russian or Muslim calendar, and Ottoman, Tatar or Arabic idioms represent just a few of the possible domains through which an individual could express himself. Muslim individuals took action contextually, considering pragmatism in the moment alongside societal expectations. Through education in madrasas, the young Isma'il learned how to act properly, while his life experience and everyday pragmatism guided him among the available opportunities. It is at the intersection of prescribed models and everyday experience that an individual's subjectivity expressed itself most visibly.

The young Isma'il, like many of his contemporaries in Russia, did not share his father's fascination with Persianate modes of self-fashioning that revolved around Sufi practices, the cult of refined poetry, and the authority of Bukharanstyle scholarship. Isma'il opted for another type of scholarly persona that started to be increasingly popular from the turn of the century: he learned Arabic rather than Persian, he went to the central lands of Islam to learn the Qur'an and the prophetic traditions, and brought this new authority of mimetic experience of

108 The Vakhidi archive, Op. 5. D. 13, ff. 17b-18b (May 20, 1914).

109 The Vakhidi archive, Op. 5. D. 13, f. 38a (May 26, 1917). 
Islam to his homeland. Isma'il was open to print media, where he articulated the common sense of Islamic reform, but it seems he reserved the performance of emotions for the private sphere.

From the evidence presented above, we see that letter production as a genre with its strict rules was supported by a plethora of writing vehicles: not just letters as such, but also notebooks and registers that documented the flow of correspondence. While matters of immediate concern forced the actors of communication to preserve their correspondence, it was emotional constellations that defined what would eventually survive in private collections and why; and, by extension, what would ultimately arrive at the historian's desk. Letters therefore appear not only as repositories of emotions, but also as objects that are themselves emotive, and hence meant to be preserved as such.

Acknowledgements: I would like to thank Ilham Gumerov, Dasha Dorodnykh, Mansur Gazimzianov, Danis Garaev, Dinara Mardanova, Eva Rogaar, and Michael Kemper as well as the anonymous reviewers of Asiatische Studien for their encouraging comments on the drafts of this article. This research has been supported by the ERC Starting Grant "MIND: The Muslim Individual in Imperial and Soviet Russia” (ERC-2018-STG).

\section{Bibliography}

'Abidi, Isma'il (1914): Imamnarga yulbash. Kazan: n.p.

'Abidi, Isma'il (1917): Mihrab irshadläre. Kazan: n.p.

Algazi, Gadi (2016): "Exemplum and Wundertier: Three Concepts of the Scholarly Persona". BMGN - Low Countries Historical Review 131.4: 8-32.

Aykut, Abdulsait (2015): The Intellectual Struggle of Murād Ramzī (1855-1935) an Early 20th Century Eurasian Muslim Author. Unpublished PhD thesis. Wisconsin-Madison University.

Babadjanov, Bakhtiyar (2007): Zhurnal "Haqīqat" kak zerkalo religioznogo aspekta v ideologii dzhadidov. (TIAS Central Eurasian Research Series). Tashkent/Tokyo: University of Tokyo.

Barudi, Galimdjan (2018): Khatirä däftäre: 1920 elnïng oktiabrennän alïp 1921 elnïng noiabrenä kadär. Ed. Aidar Gainetdinov and Ruslan Khäbibullin. Kazan: Institut istorii.

Bospflug, Elizabeth (2017): “The Muslim 'Federalist Debate' in Revolutionary Russia”. $A b$ Imperio 2017.1: 131-162.

Bustanov, Alfrid (2017): “Against Leviathan: on the Ethics of Islamic Poetry in Soviet Russia”. In: The Piety of Learning: Islamic Studies in Honor of Stefan Reichmuth. Edited by Michael Kemper, Ralf Elger. Leiden: Brill, 199-224.

Bustanov, Alfrid (2018): "Muslim Literature in the Atheist State: Zainap Maksudova between Soviet Modernity and Tradition”. Journal of Islamic Manuscripts 9.1: 1-31.

Bustanov, Alfrid (2019a): “Speaking ‘Bukharan’: the Circulation of Persian Texts in Imperial Russia”. In: The Persianate World: the Frontiers of a Eurasian Lingua Franca. Edited by Nile Green. Berkeley: University of California Press, 193-206. 
Bustanov, Alfrid (2019b): Biblioteka Zainap Maksudovoi. Moscow: Mardjani Foundation. Bustanov, Alfrid, Kemper, Michael (2017): “Russia's Islam and Orthodoxy beyond the Institutions: Languages of Conversion, Competition and Convergence". Islam and Christian-Muslim Relations 28.2: 129-139.

Denisov, Denis (2011): Ocherki po istorii musul'manskikh obshchin Cheliabinskogo Kraia (18nachalo $20 \mathrm{Vv}$. Moscow: Mardjani Foundation.

DeWeese, Devin (2016): "It Was a Dark and Stagnant Night ('til the Jadids Brought the Light): Clichés, Biases, and False Dichotomies in the Intellectual History of Central Asia”. Journal of the Economic and Social History of the Orient 59.1-2: 37-92.

Dmitrieva, Liudmila (1980): Opisanie tiurkskikh rukopisei Instituta vostokovedeniia. III. Poeziia i kommentarii k poeticheskim sochineniiam, poetika. Moscow: Nauka.

Downes, Stephanie/Holloway, Sally/Randles, Sarah (eds.) (2018): Feeling Things: Objects and Emotions through History. Oxford: Oxford University Press.

Faizrakhmanov, Il'shat (2014): Istoriia kazanskogo admiralteistva (1718-1830). Kazan: Institut istorii.

Fathi, Albert (2018): “Gabdelzhäbbar Kandalyi shigyr’äre zhyentygy”. In: Fänni Tatarstan 2018.1. Edited by Alfrid Bustanov. Kazan: Academy of Sciences, 166-168.

Frank, Allen J. (2001): Muslim Religious Institutions in Imperial Russia. The Islamic World of Novouzensk District and the Kazakh Inner Horde, 1780-1910. Leiden/Boston/Köln: Brill.

Frank, Allen J. (2012): Bukhara and the Muslims of Russia: Sufism, Education, and the Paradox of Islamic Prestige. Leiden/Boston: Brill.

Gainetdinov, Masgud (ed.) (2014): Bez elek tä bez idek. Kazan: Tatarstan kitap näshriyatï.

Geraci, Robert P. (2001): Window on the East: National and Imperial Identities in Late Tsarist Russia. Ithaca/London: Cornell University Press.

Gosmanov, Mirkasym/Märdanov, Raif (2014): "Shura" zhurnalynyng bibliografik kürsätkeche. Kazan: Milli kitapkhanä.

Green, Nile (2013): "Spacetime and the Muslim Journey West: Industrial Communications in the Making of the "Muslim World”". The American Historical Review 118.2: 401-429.

Gully, Adrian (2008): The Culture of Letter-Writing in Pre-Modern Islamic Society. Edinburgh: Edinburgh University Press.

Gumerov, Ilham (ed.) (2017): Dukhovnoe nasledie: poiski i otkrytiia. Vol. 4: Said Vakhidi. Kazan: Institut iazyka i literatury.

Isaev, Gabdelbari (2019): Dini äsärlär. Ed. by Alfrid Bustanov. Kazan: Kazanskaia nedvizhimost'.

Jolly, Margaretta/Stanley, Liz (2005): “Letters as/not a genre”. Life Writing 2.2: 91-118.

Kane, Eileen (2015): Russian Hajj. Empire and the Pilgrimage to Mecca. Ithaka, NY: Cornell University Press.

Kefeli, Agnes Nilüfer (2014): Becoming Muslim in Imperial Russia: Conversion, Apostasy, and Literacy. Ithaca/London: Cornell University Press.

Khakov, Vakhit (1972): Tatar milli ädäbi teleneng barlïka kilüe häm üseshe. Kazan: KGU.

Märdanov, Raif (2001): “Shura” zhurnaly (1908-1917). Ädäbiiat mäs’äläläre. Kazan: Milli kitapkhanä.

Märdanov, Raif (2013): Sörgen khatlarï. Kazan: Milli kitapkhanä.

Märdanov, Raif (2018): Aldïm kaläm, yazdïm sälam ... khatlar. Kazan: Milli kitapkhanä.

Meyer, James (2013): "Speaking Sharia to the State: Muslim Protesters, Tsarist Officials, and the Islamic Discourses of Late Imperial Russia”. Kritika: Explorations in Russian and Eurasian History 14.3: 485-505. 
Naganawa, Norihiro (2007a): “Maktab or School? Introduction of Universal Primary Education among the Volga-Ural Muslims". In: Empire, Islam, and Politics in Central Eurasia. Edited by Tomohiko Uyama. Sapporo: Slavic Research Center, 65-97.

Naganawa, Norihiro (2007b): "Islam and Empire Observed: Muslims in the Volga-Ural Region after the 1905 Revolution”. In: Imperiology: from Empirical Knowledge to Discussing the Russian Empire. Ed Kimitaka Matsuzato. Sapporo: Hokkaido University, 68-84.

Naganawa, Norihiro (2012a): “The Hajj Making Geopolitics, Empire, and Local Politics: A View from the Volga-Ural Region at the Turn of the Nineteenth and Twentieth Centuries". In: Central Asian Pilgrims: Hajj Routes and Pious Visits between Central Asia and the Hijaz. Edited by Alexandre Papas, Thomas Welsford, Thierry Zarcone. Berlin: Klaus Schwarz Verlag, 168-198.

Naganawa, Norihiro (2012b): "Holidays in Kazan: the Public Sphere and the Politics of Religious Authority among Tatars in 1914". Slavic Review 71.1: 25-48.

Naganawa, Norihiro (2017): Islamic Russia: Empire, Religion, and the Public Sphere, 1905-1917. Nagoya: Nagoya University Press.

Ozyuksel, Murat (2014): The Hejaz Railway and the Ottoman Empire: Modernity, Industrialisation and Ottoman Decline. London/New York: I.B. Tauris.

Paret, R. (n.d.): “Așhāāb al-Kahf”. Encyclopaedia of Islam, Second Edition. Edited by P. Bearman, Th. Bianquis, C.E. Bosworth, E. van Donzel, W.P. Heinrichs.

Paul, Hermann (2019): “Introduction. Scholarly Personae: What They are and Why They Matter". In: How to Be a Historian: Scholarly Personae in Historical Studies, 1800-2000. Edited by Hermann Paul. Manchester: Manchester University Press.

Pickett, James/Sartori, Paolo (2019): "From the Archetypical Archive to Cultures of Documentation". Journal of the Economic and Social History of the Orient 62: 773-798.

Polosin, Valerii (2015): Muslim Manuscripts: Quantitative Methods of Research. Selected Articles. St Petersburg: MAE RAS, Manuscripta Orientalia.

Randolph, John (2017): “Communication and Obligation: the Postal System of the Russian Empire, 1700-1850". In: Information and Empire. Mechanisms of Communication in Russia, 1600-1850. Edited by Simon Franklin, Katherine Bowers. Cambridge: Open Book Publishers, 155-183.

Roper, Michael (2005): "Slipping Out of View: Subjectivity and Emotion in Gender History". History Workshop Journal 59: 57-72.

Rosenwein, Barbara/Cristiani, Riccardo (2018): What Is the History of Emotions? Cambridge: Polity Press.

Ross, Danielle (2012): “The Nation that Might Not Be: the Role of Iskhaqi's Extinction after Two Hundred Years in the Popularization of Kazan Tatar National Identity among the "Ulama Sons and Shakirds of the Volga-Ural Region, 1904-1917”. Ab Imperio 3: 341-369.

Ross, Danielle (2015): “Caught in the Middle: Reform and Youth Rebellion in Russia's Madrasas, 1900-10". Kritika: Explorations in Russian and Eurasian History 16.1: 57-89.

Ross, Danielle (2019): “The Age of the 'socialist-Wahhabi-Nationalist Revolutionary': The Fusion of Islamic Fundamentalism and Socialism in Tatar Nationalist Thought, 1898-1917”. Genealogy 3.58: 1-19.

Sämitova, Gazizä (1965): Saylanma äsärlär. Ed. by Dzhavad Almaz. Kazan: Tatarstan kitap näshriyatï.

Sartori, Paolo (2018): “On Strangers and Commensurability in Eurasia: A View from 'The North”. The Indian Economic and Social History Review 55.1: 133-145. 
Scheer, Monique (2012): "Are Emotions A Kind of Practice (and is that what Makes Them Have a History)? A Bourdieuian Approach to Understanding Emotion”. History and Theory 51: 193-220.

Shaikhiev, Rafael (1990): Tatarskaia narodno-kraevedcheskaia literatura 19-20 vv. Kazan: KGU. Shäräf, Shähär (1333/1915): “Märdjanineng tärjemä-i häle”. In: Märdjani: Shihab al-Din alMardjani häzrätläreneng wälädätenä üoz yïl tulu (1233-1333) mönäsäbät ilä näsher itelde. Edited by Shähär Shäräf. Kazan: Mägarif.

Shikhaliev, Shamil/Kemper, Michael (2017): "Sayfallah-Qadi Bashlarov: Sufi Networks between the North Caucasus and the Volga-Urals". In: The Piety of Learning. Islamic Studies in Honor of Stefan Reichmuth. Edited by Michael Kemper, Ralf Elger. Leiden/Boston: Brill, 166-198.

Sibgatullina, Alfina (2010): Kontakty tiurok-musul'man Rossiiskoi i Osmanskoi imperii na rubezhe 19-20 vv. Moscow: Fond issledovanii islamskoi kul'tury.

Sood, Gagan D.S. (2007): “'Correspondence Is Equal to Half a Meeting': the Composition of Letters in Eighteenth-Century Islamic Eurasia". Journal of Economic and Social History of the Orient 50.2/3 (Spatial and Temporal Continuities of Merchant Networks in South Asia and the Indian Ocean): 172-214.

Sood, Gagan D.S. (2009): "The Informational Fabric of Eighteenth-Century India and the Middle East: Couriers, Intermediaries and Postal Communication”. Modern Asian Studies 43.5: 1085-1116.

Sood, Gagan D.S. (2016): India and the Islamic Heartlands: an Eighteenth-Century World of Circulation and Exchange. Cambridge: Cambridge University Press.

Tuna, Mustafa (2011): “Madrasa Reform as A Secularizing Process: A View from the Late Russian Empire". Comparative Studies in Society and History 53.3: 540-570.

Tuna, Mustafa (2015): Imperial Russia's Muslims: Islam, Empire, and European Modernity, 1788-1914. Cambridge: Cambridge University Press.

Usmanova, Dilyara (1996): “Die tatarische Presse 1905-1918: Quellen, Entwicklungsetappen und quantitative Analyse". In: Muslim Culture in Russia and Central Asia from the $18^{\text {th }}$ to the Early $20^{\text {th }}$ Century. Edited by Michael Kemper, Anke von Kuegelgen, Dmitriy Yermakov. Berlin: Klaus Schwarz Verlag, 239-278.

Usmanova, Dilyara (1998): “The Activity of the Muslim Faction of the State Duma and Its Significance in the Formation of a Political Culture among the Muslim Peoples of Russia (1906-1917)". In: Muslim Culture in Russia and Central Asia from the $18^{\text {th }}$ to the Early $20^{\text {th }}$ Centuries. Vol. 2: Inter-Regional and Inter-Ethnic Relations. Edited by Anke von Kuegelgen, Michael Kemper, Allen J. FranK. Berlin: Klaus Schwarz Verlag, 417-455.

Usmanova, Dilyara (2006): Musul'manskie predstaviteli v rossiiskom parlamente. 1906-1917. Kazan: KGU.

Usmanova, Dilyara (2013): “Die islamische Presse der Wolga-Ural-Region im 20. Jahrhundert: Probleme der islamischen Bildung”. In: Repression, Anpassung, Neuorientierung: Studien zum Islam in der Sowjetunion und dem postsowjetischen Raum. Edited by Raoul Motika, Michael Kemper, Anke von Kügelgen. Wiesbaden: Dr Ludwig Reichert Verlag, 215-251.

Zadeh, Travis (2016): “Uncertainty and the Archive”. In: Digital Humanities and Islamic and Middle East Studies. Edited by Elias Muhanna. Berlin: De Gruyter, 11-64.

Supplementary Material: The online version of this article offers supplementary material (https://doi.org/10.1515/asia-2019-0026). 